J. EDUCATIONAL COMPUTING RESEARCH, Vol. 45(1) 29-47, 2011

\title{
PRESERVICE TEACHERS' BELIEFS, ATTITUDES, AND MOTIVATION ABOUT TECHNOLOGY INTEGRATION*
}

\author{
THERESA A. CULLEN \\ BARBARA A. GREENE \\ University of Oklahoma
}

\begin{abstract}
The Theory of Planned Behavior was used as a framework, along with Self-Determination Theory, to examine preservice teachers' motivation to include technology in their future teaching. We modified instruments to measure theoretical constructs to be applied to plans for the use of technology. Measured were: perceived behavioral control, attitudes toward technology use, perceived social norms, intrinsic and extrinsic motivation and amotivation. One hundred and fourteen preservice teachers completed the instrumentation and 67 completed a pre/post activity and reflective task concerning their attitudes and beliefs on technology, technology integration, and its role in the classroom. The best single predictor of both intrinsic and extrinsic motivation was positive attitudes toward technology use. For amotivation, the best predictors were negative attitudes toward technology use and negative social norms. The pre-post activity demonstrated that participants struggled to design meaningful technology integration activities.
\end{abstract}

*A previous version of the article was presented at the 2010 AERA annual meeting in Denver, Colorado.

(c) 2011, Baywood Publishing Co., Inc.

doi: 10.2190/EC.45.1.b

http://baywood.com 
Trying to predict whether or not those studying to be teachers will use technology is a long running challenge (Ertmer, 2005). During the 1990's, millions of federal money was spent on the Preparing Tomorrow's Teachers to Teach with Technology (PT3) grants. These programs provided a variety of interventions to help teachers use technology; however most did not explore the basic beliefs held by preservice teachers about technology integration (ALTec, 2002; Ottenbreit-Leftwich \& Cullen, 2006). Both Ertmer (2005) and Hew and Brush (2007) have argued that this lack of knowledge about preservice teacher's beliefs is a key gap in our knowledge about intentions to use in technology in future classrooms. More research is needed to understand why teachers - both preservice and inservice-choose to use technology or not (Ertmer \& Ottenbreit-Leftwich, 2010; Hew \& Brush, 2007). Our study aims to examine a combination of psychological and social constructs to better understand the beliefs, attitudes and motivations of preservice teachers to use technology.

A teacher's choice to use or not use technology is multifaceted. Hancock, Bray, and Nason (2002) found that student success in a technology course was a complex combination of personality traits and the learning environment. They measured achievement based on course grades and motivation scores; however, the true test of successful technology instruction was if preservice teachers finished with positive beliefs about classroom technology use. For the current study, we chose to use the Theory of Planned Behavior (Ajzen, 1991) as a framework to examine whether preservice teachers are motivated to use technology in their future classrooms.

\section{Theoretical Framework}

For our purposes, the term technology integration refers to the use of technology in a teacher's regular teaching and curricular plans. Pierson (2001) argued that to evaluate the integration decisions made by teachers, we must acknowledge that technology integration depends on the beliefs that teachers hold, the technologies that are available, and the expectations that are perceived. For our study, we used the Theory of Planned Behavior (TPB) (Ajzen, 1991) to capture the three components identified by Pierson (2001). The Theory of Planned Behavior focuses on three constructs proposed to be necessary to predict a behavioral outcome: attitude, subjective norm (what the participants believe others to think of the behavior) and perceived behavioral control (how much power the participant believes they have over the choice to do the behavior) (Madden, Ellen, \& Ajzen, 1992). Sugar, Crawley and Fine (2005) suggested that it is an appropriate framework to focus participant responses on their attitudes toward technology integration practices and away from general teaching practices. We will discuss each of the three constructs of the model in light of the available research on technology use. 
Attitude

Ajzen (2005) reported that attitudes, which are positive and negative judgments that are constructed out of our beliefs and experiences, are primary indicators of a person's intent to perform a behavior. When examining Korean teachers' intention to integrate technology in their teaching, researchers found that attitude was a much greater indicator of a teacher actually using technology than their perceptions of what others believed or of their control to do so (Lee, Cerreto, \& Lee, 2010). A study of student teachers also showed attitude as the greatest predictor of their intent to use technology even above their self-efficacy about their teaching and computing skills (Sang, Valcke, vanBraak, \& Tondeur, 2010).

Beliefs [like educational beliefs about technology use] are difficult to change and based on past experiences (Ajzen, 2005; Stuart \& Thurlow, 2000), but potentially go beyond the positive and negative judgments that characterize attitudes. In her review of teacher beliefs research relating to technology integration, Ertmer (2005) asserted that research was still needed to understand the role of teacher beliefs in their willingness to use technology as well as a need for new instruments to measure different teacher beliefs. Additionally, Hew and Brush (2007) challenged researchers to create clearer operational definitions of teacher beliefs about technology to encourage further study and understanding.

One way to better assess teacher beliefs is to look at their attitudes toward a behavior (Ajzen, 2006). In a study of teachers who did not change their practices after targeted professional development, Palak and Walls (2009) found the teacher's attitudes toward technology were the strongest predictors of whether or not they would incorporate technology rich instructional strategies into their classrooms. Greek teachers' specific attitudes toward technology were closely tied to their past experiences with computing (Paraskeva, Bouta, \& Papagianni, 2008). Levin and Wadmany (2006) found that classroom practices were easier to change than beliefs and that teacher's attitudes were actually based on multiple views related to a topic rather than a well-formed belief system. Another study found that teachers were motivated to use technology by their beliefs that it would make them better teachers and make students behave better (Lee, Ceretto, \& Lee, 2010). Thus, beliefs are durable and strongly related to behavior. Attitudes, a specific manifestation of beliefs, were studied in the present investigation. Other beliefs important to the present study are beliefs about the self and beliefs about whether or not one will be able to operate autonomously in the future. In the Ajzen model, these are known as beliefs about personal control. They will be discussed following a discussion of the role of beliefs about social expectations.

\section{Perceived Social Norms}

Preservice teachers often have a difficult time understanding the teaching environment to which they aspire (Choy, Wong, \& Gao, 2009). They base many of 
their teaching decisions on their perceptions of the environment largely based on their own experiences as K-12 students (Lei, 2009; Stuart \& Thurlow, 2000). Their perceptions of the learning environment, and especially of their colleagues, can be an important factor for successful induction into the field of teaching. Smarkola (2008) found that preservice teachers were motivated by a variety of factors that included wanting to be well-perceived by their peers, especially administrators. Several studies that examined a diffusion of innovations framework demonstrated that a participant's perception of what others think of the innovation is an important part of the model (Frank, Zhao, \& Borman, 2004; Wong, 2004). Frank, Zhao, and Borman (2004) found that the participants' perception of others' opinions of technology were very important, and were only eclipsed by access to technological expertise. Wong (2004) stated, "Teachers want and need to belong. If they do not belong in a positive way, they will belong in a negative way" (p. 52). He argued that to have beginning teachers thrive there must be a strong learning community. In our study we examined how beliefs about positive and negative social norms for technology use might influence motivation to use technology in future teaching.

\section{Perceived Behavioral Control}

Perceived Behavioral Control refers to a person's belief concerning whether or not he/she has the power to influence the outcome of some targeted behavior. It is very similar to Bandura's notion of self-efficacy (Bandura, 1986), which is the degree to which a person is confident that he/she can successfully engage in some behavior or complete some task. This facet is especially interesting for offering insights about teachers' technology use because their willingness to integrate technology is tied to their self-efficacy for using computers (Wozney, Venkatesh, \& Abrami, 2006) and the barriers they experience in their teaching setting (Cuban, Kirkpatrick, \& Peck, 2001). Sølvberg (2003) found that students control beliefs about using technology increased as they became more knowledgeable, and with higher control beliefs would persist in using technology even when encountering difficulties. In one study, Sang et al. (2010) paired participants' perceived ability to complete tasks along with their perception of the resources and opportunities available to them. Although they found attitude to be the strongest predictor, Sang et al. (2010) found that self-efficacy concerning teaching and computer skills was a major contributor to student teachers intention to use technology, as well as, the ability to overcome common barriers to integration such as lack of resources.

Self-efficacy may also impact other areas of the model. Wozney et al. (2006) sought to parse out what was the most important aspect of attitude as a predictor of teachers' use of technology. They found that teachers must believe that they will have the skill and ability to use the technology with students before they are willing to try to use it (Wozney et al., 2006). Ward and Parr (2010) supported 
this finding when they found that teachers' readiness to even consider using technology was influenced by both skill and confidence in their ability to use technology. Smarkola (2008) found that some teachers believed that they would have very little control over their learning environments and would be limited by the resources available to them in their schools. This research encouraged us to include perceived behavioral control in our study, including a measure of self-efficacy or, more specifically, perceived competence (Williams \& Deci, 1996).

\section{Self-Determination Theory of Motivation}

Motivation is comprised of internal and external components of human life that encourage or discourage behaviors. Ryan and Deci (2000) proposed a meta-theory of motivation called Self-Determination Theory (SDT) that they use to capture the many facets of motivation. The overarching theory characterizes motivation as a natural function of human development, as people move toward and away from the different challenges that are present in different contexts throughout the life span. There are five subtheories within SDT, but for our purposes we are interested in, first, the key distinction between types of motivation (amotivation, extrinsic, and intrinsic motivation) from their Cognitive Evaluation Theory that is central to understanding behaviors and, second, the Basic Psychological Needs Theory (BPNT) because it is important for predicting those three types of motivation (Deci \& Ryan, 2008).

There is considerable evidence that people who are intrinsically motivated, or energized by an internal drive to engage in some activity, will be more persistent, more self-regulated, will enjoy the process; and perform better (e.g., Benware \& Deci, 1984; Deci \& Ryan, 2008; Deci \& Vansteenkiste, 2004; Elliot \& Dweck, 1988; Elliot \& Harackiewicz, 1994; Gottfried, 1990; Pintrich \& DeGroot, 1990; Reeve, 2001, 2002; Ryan \& Deci, 2000). This is why intrinsic motivation is often conceived of as the pinnacle of motivation. Extrinsic motivation, on the other hand, exists when people are energized by seeking some reward that is external to the activity itself. It is not associated with enjoyment, persistence, etc, but it also is not the worse case of motivation, which is amotivation. When people have extrinsic motivation they are still interested in performing an activity, but the focus is on the reward rather than the activity itself. Amotivation occurs when people see absolutely no point in engaging in an activity. This is truly the worse case for motivation. Although promoting intrinsic motivation is always preferred in learning settings, the reality is that many students will be extrinsically motivation for most activities in their different learning settings (Ryan \& Deci, 2000).

One way to better understand how to encourage intrinsic motivation is through BPNT (Deci \& Ryan, 2000). In SDT, the focal basic needs are autonomy, relatedness, and competence. The need for autonomy is the need to feel in control 
of one's actions. Contexts that allow people to make choices and work toward meaningful goals have been found to promote intrinsic motivation. The need for relatedness is associated with the need to feel connected to the people and ideas in a given setting. Contexts that encourage people to feel that they belong tend to also support intrinsic motivation. The need for competence is essentially the same as the need for self-efficacy. People need to have confidence that their actions will yield desired outcomes. It is difficult for people to develop intrinsic motivation if they are not confident enough to engage in the activities central to a given context.

We noted that all three of these basic needs are aspects of TPB. Both the needs for autonomy and competence are captured by the perceived behavioral control factor. The need for relatedness is very similar to perceived social norms. Our recognition that these two theories (TPB \& SDT) were overlapping on some key elements lead to our decision to use the three types of motivation as our measures of intention. This decision is consistent with the intent of the Theory of the Planned Behavior since the theory looks at both internal and external factors that influence whether someone will perform the behavior. Therefore, we found that the aspects of the Theory of Planned Behavior was an appropriate framework that would encompass the complex reasons for choosing (or not choosing) to integrate technology among preservice teachers as well as incorporate key psychological constructs that could contribute to technology integration choices.

\section{PURPOSE AND RESEARCH QUESTION}

Building on the literature reviewed above, the purpose of this study is to better understand the beliefs and motivations of preservice teachers related to their plans to integrate technology into their future teaching. Therefore we designed a study to address the question: Do the variables suggested by the Theory of Planned Behavior and Self Determination Theory predict preservice teachers' intentions/motivations to use technology?

\section{METHOD}

\section{Sample and Context}

Participants were 114 preservice teachers from six sections of a required undergraduate technology integration course in a large southwestern public research university. The data were collected from the same course over two semesters. The students were studying all different areas of education from early childhood and elementary to specific content areas including language arts, social studies, math, and science. Students were in the semester before student teaching and were also enrolled in their third field experience in an urban setting but none had had significant teaching experience. The course was designed based on the ISTE National Educational Technology Standards for teachers (ISTE, 
2008) and all preservice teachers had also completed a prerequisite course that assured they had basic computer proficiency and productivity skills. Although preservice teacher participation was voluntary, participants earned 5 points extra credit for completion (out of 400 possible points in the course). Preservice teachers who completed the instruments also completed informed consent to allow researchers to examine reflections that they completed at the beginning and the end of the course. The instruments were available online for preservice teachers to complete during the last 2 weeks of the semester. All 114 participants completed the online survey, and 67 preservice teachers were able to complete the pre- and post-reflections. To avoid any conflicts of interest, one of the authors was an instructor of two sections of the course, the other researcher or a graduate student completed recruitment in those sections.

\section{Instruments}

The participants completed an online questionnaire that consisted of 50 6-point Likert-type items that ranged from strongly disagree (1) to strongly agree (6). While our overall framework was based on the TPB (Madden, Ellen, \& Ajzen, 1992), we used items from multiple scales to measure different constructions and modified them to fit our context, including two from SDT (Deci \& Ryan, 2000). For representing perceived behavior control, we developed six items related to expecting choice (in the future) and used four items measuring perceived competence that we modified from Williams and Deci (1996). We developed five items each for positive and negative aspects of subjective norms. For attitudes we had seven items each for positive and negative attitudes toward use of technology from the Teachers' Attitudes Toward Computers (TAC) instrument (Knezek \& Christensen, 2011). Finally, we measured motivation to use technology with an instrument in terms of intrinsic and extrinsic motivation and amotivation based on items used by Vallerand, Pelletier, Blais, Briele, Senical, and Vallieres (1992). We used the three motivation variables as our proxies for Intention in the Ajzen (1991) model. We examined whether or not the attitudes, subjective norms and behavioral control variables predicted each of the three motivation variables. Sample items are shown in Table 1 along with the descriptive statistics.

Although we planned for a measure of behavior, based on a reflective pre- and post-course activity, the product that preservice teachers created was not in fact useable for that purpose since the responses differed too greatly to be summarized into a comparable numerical value. Instead we found this data useful when analyzed qualitatively to give us deeper insight into the attitudes and beliefs of the preservice teachers about technology and social norms in school settings. At the beginning of the class, the preservice teachers were asked to respond to a prompt, "Using a topic from your content area specialty or desired grade level, describe an ideal lesson that uses technology." They were asked to describe the 
Table 1. Sample Items and Descriptive Statistics for Survey Results

\begin{tabular}{|c|c|c|c|}
\hline Variables and number of items & Mean & $\begin{array}{l}\text { Std. } \\
\text { dev. }\end{array}$ & $\begin{array}{l}\text { Cronbach } \\
\text { alpha }\end{array}$ \\
\hline \multicolumn{4}{|l|}{$\begin{array}{l}\text { Motivation toward using technology in future } \\
\text { teaching }\end{array}$} \\
\hline $\begin{array}{l}\text { Extrinsic goals for using technology - } 6 \text { items } \\
\text { I would receive better evaluations from my } \\
\text { administrators if I were using technology in } \\
\text { my teaching. }\end{array}$ & 3.62 & .81 & .81 \\
\hline $\begin{array}{l}\text { Intrinsic personal beliefs about tech - } 5 \text { items } \\
\text { I use technology because I think that } \\
\text { technology will help me better prepare my } \\
\text { students for future careers. }\end{array}$ & 3.02 & .78 & .89 \\
\hline $\begin{array}{l}\text { Amotivation toward using technology - } 2 \text { items } \\
\text { I once had good reasons for learning to use } \\
\text { technology, however, now I wonder whether } \\
\text { I should continue. }\end{array}$ & 3.62 & .92 & .67 \\
\hline \multicolumn{4}{|l|}{ Attitude } \\
\hline $\begin{array}{l}\text { Positive attitudes about Tech }-7 \text { items } \\
\text { I enjoy doing things with technology. }\end{array}$ & 4.22 & .83 & .82 \\
\hline $\begin{array}{l}\text { Negative attitudes about Tech }-7 \text { items } \\
\text { Computers hate me. }\end{array}$ & 2.56 & .86 & .82 \\
\hline \multicolumn{4}{|l|}{ Subjective Norm } \\
\hline $\begin{array}{l}\text { Positive Social Responses to technology use - } \\
5 \text { items } \\
\text { My students would appreciate using } \\
\text { technology in class. }\end{array}$ & 4.20 & .74 & .84 \\
\hline $\begin{array}{l}\text { Negative Social Responses to technology use - } \\
5 \text { items } \\
\text { Other teachers will think I am showing off } \\
\text { if I use technology in my teaching. }\end{array}$ & 2.25 & .76 & .78 \\
\hline \multicolumn{4}{|l|}{ Perceived Behavioral Control } \\
\hline $\begin{array}{l}\text { Positive choice in teaching - } 6 \text { items } \\
\text { Given curricula, standards, and testing } \\
\text { constraints, I will still have a lot of control over } \\
\text { my teaching in the future. }\end{array}$ & 3.85 & .71 & .84 \\
\hline $\begin{array}{l}\text { Self-efficacy }-4 \text { items } \\
\text { I feel confident in my ability to learn about } \\
\text { technology. }\end{array}$ & 4.66 & .93 & .91 \\
\hline
\end{tabular}

Note: $N=114$ 
roles of teachers and students in the lesson and what they thought other teachers, administrators, parents, and students would think of it. They completed this activity at the end of the course and wrote a one-page reflection comparing their two lessons and how their attitude toward technology in the classroom had changed. Initial analysis of the written responses were coded to identify references to the participants' attitudes and motivation, social norms and perceived behavioral control, as well as the teacher versus student centered nature of their final lesson plans.

For responses to the pre- and post-open-ended reflections, we used the constant comparative method (Bogdan \& Biklen, 1998; Glaser \& Strauss, 1967) in which we developed a coding guide using an emergent coding scheme in both the pre- and post-measures. We developed the guide by first coding five responses together, and then an additional five at another time to verify that our coding guide was clear and would support independent coding. Any differences were discussed, consensus was reached and the coding guide was clarified. Next we coded 20 reflections independently, and then checked for agreement. Consensus was reached and only minor clarifications were added to the coding guide. Finally, the last 37 were coded independently. The coders met again and systemically sampled from the coded responses to check for agreement. Any differences were discussed and consensus was reached.

\section{RESULTS}

\section{Quantitative Findings}

All of the scales were evaluated for their reliability, using Cronbach alphas, and all were in the acceptable range, as can be seen in Table 1. The lowest coefficient alpha was .78 (for negative perceived social support) and the highest was .91 (for self-efficacy). The preservice teachers generally had moderately positive attitudes toward technology as can be seen by the means reported in Table 1 . The only means that were below 3.0 on our 6-point Likert scale were for scales or items that captured negative attitudes, negative social norms, or amotivation.

The inter-correlations are shown in Table 2. It is interesting to note that the highest positive correlations were between intrinsic and extrinsic motivation, self-efficacy and positive social norms, and amotivation and negative attitudes. The three highest negative correlations were between the negative attitudes variable and self-efficacy, intrinsic motivation, and positive attitudes. From Table 2 we can also see that the high-choice variable had the least number of statistically significant correlations. In fact there were only two correlations greater than .20 for the high-choice variable.

We next used regression analyses to examine the pattern of predictions for the three motivation variables. We used the simultaneous entry procedure wherein 
38 / CULLEN AND GREENE

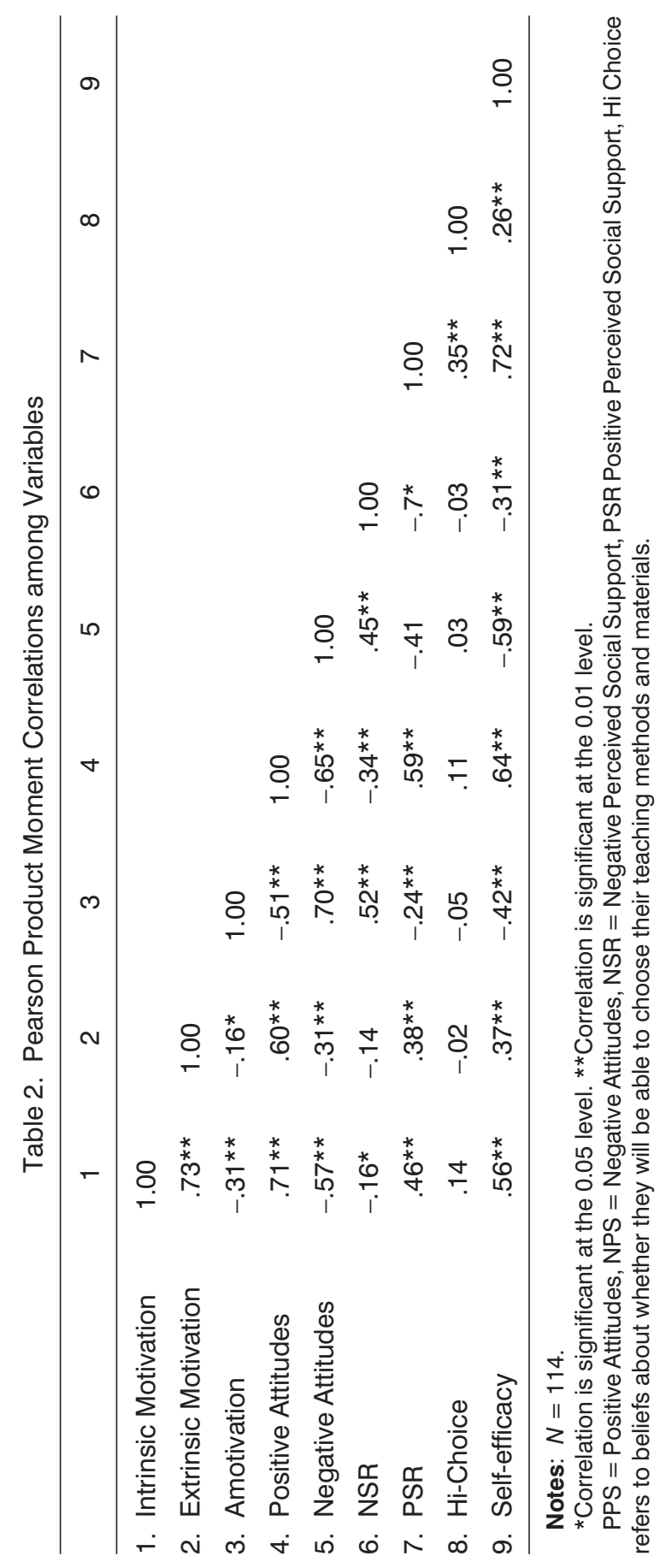


all six predictor variables were entered into the equation together. For the prediction of intrinsic motivation, we found that $53 \%$ of the variance was explained by the six variables $(F(6,113)=22.29, p<.0001)$. The significant Beta values were for positive attitudes $(.56, p<.0001)$, negative attitudes $(-.21, p=.03)$, and negative social norms $(.15, p=.03)$. The positive Beta value for negative social norms is inconsistent with the finding of a negative bi-variate correlation. For the prediction of extrinsic motivation, we found that $35 \%$ of the variance was explained by the six scores $(F(6,113)=11.07, p<.0001)$. However, the only significant Beta value was for positive attitudes $(.655, p<.0001)$. The final equation was for the prediction of amotivation. We found that $52 \%$ of the variance was explained $(F(6,113)=21.83, p<.0001)$. In this case, negative attitudes and negative social norms were the variables with the statistically significant Beta values $(.54$ and .25 respectively, $p<.001)$.

\section{Pre/Post and Reflection Results}

Sixty-seven preservice teacher responses were analyzed, using the constant comparison method, after frequency counts were done. We found that preservice teachers showed a greater likelihood to use technology after being enrolled in the technology integration course. We found that the lessons early in the course (i.e., at pretest) were dominated by uses of PowerPoint and Word, which were the software packages that were familiar to the preservice teachers. At the end of the course (i.e., at posttest), as expected, student reflections were dominated by tools that they had learned about, including Smartboards and concept mapping software. Sixty-one percent were very likely or likely to use technology in teaching at pretest, while $74 \%$ were very likely or likely at posttest. At both pre- and posttests, there was a group of about $24 \%$ who explained that they would only use technology selectively. At the beginning of the course, $66 \%$ discussed positive attitudes toward technology, whereas $92 \%$ reported positive attitudes at posttest.

\section{Attitude}

The attitudes at pretest varied from interested in using technology, to considering its use just makes sense, to worries about what might be lost to technology. Preservice teachers acknowledged that technology is used everyday. For example, one preservice teacher wrote, "I support technology in the classroom because it's our society's way of life now ... I think it's important to teach children how to use this technology in an age (and material) appropriate way, rather than ignoring it and hoping it goes away." Use what you have available was one preservice teacher's attitude, "If the school is lucky enough to have access to some of this technology, it would be a waste not to use it." Another preservice teacher explained, "I like it up to a point. I think that sometimes the use of technology takes students away from more creative and freethinking aspect because computers and Smartboards can be distracting." The concern over 
too much technology was a recurrent theme, as shown by the comment, "I also feel like too much technology allows the students to become dependent on the technology and not as much on their own learning." A male preservice teacher, who was concerned that technology could be seen as a replacement for effective teaching, said, "Nothing can replace a teacher who can explain the material in plain terms that students can understand."

Preservice teachers maintained this cautious attitude, but overall were much more in favor of using technology at posttest. For example, one preservice teacher initially said she would reluctantly use technology because she did not want to "disadvantage" her students, but that "The classroom is a safe and controlled (as much as possible) environment that is good for the learning of technology." After the course, she explained, "It is useful, but I do not want to use it a lot." Preservice teacher responses were longer and more carefully qualified at posttest; they were not just more pro-technology without careful consideration and support. A student explained, "I am still not entirely comfortable with complicated technology, so while I plan on incorporating all of the technology I learned to use to use in this class, I don't think I will be using a lot of complicated technology without someone there to teach me how to use it."

The same student went on to explain that her reluctance came down to rules, "I do not want a bunch of second graders surfing the Internet at home because their teacher said it was OK. Although I will give guidelines and rules, I know students can twist words easily." Other comments demonstrated that preservice teachers were still concerned that technology would take away from student learning of specific content. A secondary English education major explained, "I am not very open to technology, and I cannot think of too many ways to use in it the English classroom that are not distracting." This is consistent with other studies that show that preservice teachers are often concerned with classroom management and distraction when it comes to technology (Erdoğan, Kurşun, Şişman, Saltan, Gök, \& Yildiz, 2010; Hew \& Brush, 2007) and may show the interplay between attitude and their self-efficacy and perceived behavioral control beliefs.

\section{Perceived Behavioral Norm and}

Perceived Behavioral Control

Preservice teachers were also asked what they thought others would think of their technology integration lesson plan if they were to observe it or experience it. When asked about expected administrators' views, the most common answer was that administrators would approve (49\% at pretest and $64 \%$ at post). For parents, approval was also important with 51\% hoping that parents would approve of their lesson before the class and 58\% hoping they would approve of the lesson they submitted after the class. For students, the preservice teachers were 
most concerned that students would see learning with technology as fun $(61 \%$ at both pre and post). However they also stated that it would be different (16\% pre $/ 24 \%$ post), with some of these responses comparing technology to "more than using worksheets."

Preservice teachers were also asked if they felt they would be able to teach the lesson they planned, and if not why. This was asked to gather insight on their perception of the control and resources they expected to have in their future classroom teaching. At the end of the semester, 55\% said they would worry that they would not have access to the technology that they planned to use. This was an increase from $41 \%$. These preservice teachers comments demonstrated technology as something of an extravagance in a teaching position. A student explained, "I would probably not have the luxury of having a computer for students to use, so an alternative would be used." These kinds of comments are consistent with Smarkola's (2008) findings that teachers thought they would lack resources and control. Additionally, their concerns about students knowing how to use computers increased from $5 \%$ to $20 \%$. But their worries about their own knowledge decreased from $13 \%$ to $2 \%$ ). This paired with their concerns about classroom management discussed earlier, does indicate that issues of control are relevant to their technology integration choices.

\section{General Trends}

In discussing the pre-and post-results the coders noticed a few trends. In general, the students reported that even everyday uses of technology would be viewed as groundbreaking or innovative. For example, comments included that every day use of technology would "impress" administrators and other teachers and they might be perceived as "showing off" by using technology. One preservice teacher's response showed a mix of concern and a desire to impress other educators. She thought, "Other teachers and administrators would probably think it was dangerous or a long shot to have children so young working with something so foreign, new, and expensive. However, they would probably be amazed and encouraged when they see them working carefully and efficiently." In addition, many of the lessons that preservice teachers submitted greatly underestimated what a child at that particular age could do. For example, planning for third graders to drag and drop objects into a box on a Smartboard or having fourth graders require assistance to operate a mouse for movie editing or creating a PowerPoint. One preservice teacher explained that an administrator would not like her proposed use of technology, by saying, "They might think it is a little bit ridiculous to expect preschoolers to use technology." Again the preservice teachers' lack of professional experience in the classroom showed in their responses and were consistent with the findings of Choy, Wong, and Gao (2009). 


\section{DISCUSSION}

Using the motivation variables as our dependent variables produced interesting results. Overall we saw that attitude was a significant predictor of both intrinsic and extrinsic motivation to use technology. The pattern of large Beta values indicated that both positive and negative attitudes are best for understanding intrinsic motivation, while only positive attitudes were useful in predicting extrinsic motivation. This is consistent with other literature (Lee, Cerreto, \& Lee, 2010; Levin \& Wadmany, 2006; Sadaf, Newby, \& Ertmer, 2011; Smarkola, 2008) in which the importance of attitudes was noted. The finding that negative attitudes and negative social norms predicted amotivation was not surprising. Again, we noted that the more dominant predictor was attitude. We also found that self-efficacy was positively correlated with both intrinsic and extrinsic motivation. This is consistent with Self-Determination Theory in that in order to be motivated to achieve a goal, such as integrating technology into the teaching, they must feel competent and able to do the task at hand (Deci \& Ryan, (2000). Wozney, Venkatesh, and Abrami (2006) also concluded that when teachers reported being comfortable using technology, their attitudes are better, and that is when they are most likely to actually use technology. Paraskeva, Bouta, \& Papagianni (2008) found that it was a combination of self efficacy, with a positive attitude, and a desire to use technology in their teaching, that was the greatest indicator of whether teachers would actually use technology or not. Our study builds on this previous literature (Lee, Cerreto, \& Lee, 2010; Palak \& Walls, 2009; Sadaf, Newby, \& Ertmer, 2011; Shiue, 2007) in that the findings are consistent in terms of the separate variables, but our findings extend the prior knowledge in that we included self-determination theory.

The lack of influence from the measure of perceived subjective norm has also been supported by other studies. Ma, Andersson, and Oslear Streith (2005) found that perceived social norm did not contribute to whether student teachers would adopt a technology. They explained the small contribution on the fact that teachers work independently and are given great autonomy over their classrooms. Therefore, they may not be as concerned by what others may think. In our open-ended responses, preservice teachers were concerned what administrators, other teachers, and parents would think, but only to the level that their teaching would gain approval, or would not get them in trouble. Comments like "I don't think that other teachers or administrators would have a problem with this lesson" were common. This may be indicative of these soon to be teachers being unaware of the social environment in the school, and being more concerned about completing tasks associated with their jobs instead of interacting with the overall learning community (Stuart \& Thurlow, 2000).

The lack of correlations with the high choice variable is not as surprising it might seem. Choice was a variable we used with self-efficacy to represent perceived behavioral control. In other studies that looked at teachers' intention to 
use technology, one of the stated limitations is lack of resources (Becker, 2000; Cuban, Kirkpatrick, \& Peck, 2001). When we look at the 67 teachers who completed the pre and post survey - they were concerned that they would not have access to technology in their teaching setting. If they do not believe they will have the technology available to them, they are not likely to anticipate having the power to decide whether to use technology or not (Cuban, Kirkpatrick, \& Peck, 2001). Therefore, choice is not the main issue. This is not easy to reconcile with self-determination theory, but all the other findings were consistent.

\section{Significance of Study and Limitations}

The results of our study demonstrate that the two theoretical frameworks, Theory of Planned Behavor (TPB) and Self-Determination Theory, can be used to examine psychosocial issues related to technology integration. We believe that the use of these two theoretical perspectives is what makes our study unique. In future work, we hope to include a valid measure of behavior to more fully examine the issue.

Our results could be interpreted as suggesting that our participants were developing positive attitudes toward technology and reported believing that others would view using technology in their teaching positively. Knowing that a group has positive attitudes seems to indicate their intention to use technology, which suggests that this group would be a receptive audience for additional training and professional development. However, these positive attitudes do not ensure that preservice teachers will integrate technology in their careers. The development of positive attitudes toward technology, and a level of perceived personal choice in using technology, suggests that preservice teachers are ready to consider new paradigms of classroom technology integration. These findings also reinforce Ertmer's (2005) assertion that preservice teachers need more opportunities for reflection. However, our findings also suggest that these reflections need to be structured very explicitly in order to guide preservice teachers to examine their existing attitudes and yield reportable values.

As Hew and Brush (2007) and Ertmer (2005) called for in their position pieces, new instruments are needed to better understand the complex influences that define whether new educators will choose to use technology in their teaching. By looking at motivation via the self-determination characteristics of preservice teachers, along with their perceptions of how others will view technology integration activities, we as teacher educators may be able to lay the groundwork for improved views of technology activities before our preservice teachers are in their own classrooms. Our study findings are consistent with Smarkola's (2008) conclusion that the issue of technology integration should be examined beyond a school system or professional development issue, but instead should be looked at as a process informed by personal beliefs and actions based on attitudes and each teachers' confidence in their own teaching and technology use abilities. 
We would like to point out several limitations to this study. One limitation is that we did not include a useful measure of behavior. We had hoped that the change seen from the beginning to the end of the course in lesson designs and students' reflections would provide this measure. Unfortunately, we ended up not obtaining useful data. While not part of the model, other studies (Paraskeva, Bouta, \& Papagianni, 2008) found that past technology experiences were a significant predictor of technology integration intent. This should be added, if for no other reason, as a control variable in future studies. We might add a measure of previous technology experience in future work.

Finally, we think that the set of items that we used, although based on prior work and found reliable in this sample, needs to be examined using factor analysis to see where there might be overlap in the factors. There were several high intercorrelations with the two attitude variables and we are concerned that this suggests some conceptual overlap as well. Additionally, the finding of a positive Beta value (for intrinsic motivation and negative social support) when the bi-variate correlation was negative indicates that there might be collinearity problems.

We believe that these factors are interesting and warrant additional study. Plans for future studies include having more preservice teachers complete the instruments so that the items can be validated using factor analysis. Other plans include developing a measure for behavior that will capture whether or not the preservice teachers actually choose to use technology when given the choice during student teaching. Other studies (Choy, Wong, \& Gao, 2009) have concluded that more studies are needed to examine how intention translates into practice in the real-life classroom and therefore we would propose visiting teachers once employed. Observations and documentation of actual classroom use would likely provide the technology integration research community a more robust predictive model to better shape preservice curricula and design more appropriate learning experiences in increase teacher technology use in the future.

\section{REFERENCES}

ALTec (2002). Lessons learned \& links to featured grants on PT3.org. Retrieved from http://www.pt3.org/stories/lessonslearned.html

Ajzen, I. (1991). The theory of planned behavior. Organizational Behavior and Human Decision Processes, 50, 179-211.

Ajzen, I. (2005). Attitudes, personality and behavior. New York: Open University Press.

Ajzen, I. (2006). Constructing a TpB questionnaire: Conceptual and methodological considerations. Retrieved from http://www.people.umass.edu/aizen/pdf/tpb. measurement.pdf

Bandura. A. (1986). Social foundations of thought and action: A social cognitive theory. Englewood Cliffs, NJ: Prentice-Hall. 
Becker, H. J. (2000). Findings from the teaching, learning, and computing survey: Is Larry Cuban right? Education Policy Analysis Archives, 8(51). Retrieved from http://epaa.asu.edu

Benware, C. A., \& Deci E. L. (1984). Quality of learning with active versus passive motivational set. American Educational Research Journal, 21, 755-765.

Bogdan, R. C., \& Biklen, S. K. (1998). Qualitative research for education (3rd ed.). Needham Heights, MA: Allyn and Bacon.

Choy, D., Wong, A. F. L., \& Gao, P. (2009). Student teachers' intentions and actions on integrating technology into their classrooms during student teaching: A Singapore study. Journal of Research on Technology in Education, 42(2), 175-195.

Cuban, L., Kirkpatrick, H., \& Peck, C. (2001). High access and low use of technologies in high school classrooms: Explaining an apparent paradox. American Educational Research Journal, 38(4), 813-834.

Deci, E. L., \& Ryan R. M. (2000). Self-determination theory and the facilitation of intrinsic motivation, social development, and well-being. American Psychologist, 55, 68-78

Deci, E. L., \& Ryan, R. M. (2008). Facilitating optimal motivation and psychological well-being across life's domains. Canadian Psychology, 49, 14-23.

Deci, E. L., \& Vansteenkiste, M. (2004). Self-determination theory and basic need satisfaction: Understanding human development in positive psychology. Ricerche di Psichologia, 27, 17-34.

Elliott, E. S., \& Dweck, C. S. (1988). Goals: An approach to motivation and achievement. Journal of Personality and Social Psychology, 54, 5-12.

Elliott, E. S., \& Harackiewicz, J. M. (1994). Goal setting, achievement orientation, and intrinsic motivation: A mediational analysis. Journal of Personality and Social Psychology, 66, 968-980.

Erdoğan, M., Kurşun, E., Tan Şişman, G., Saltan, F., Gök, A., \& Yildiz, İ. (2010). A qualitative study on classroom management and classroom discipline problems, reasons, and solutions: A case of information technologies class. Kuram ve Uygulamada Egitim Bilimleri, 10(2), 881-891.

Ertmer, P. A. (2005). Teacher pedagogical beliefs: The final frontier in our quest for technology integration? Educational Technology Research and Development, 53(4), 25-39.

Ertmer, P. A., \& Ottenbreit-Leftwich, A. T. (2010). Teacher technology change: How knowledge, confidence, beliefs, and culture intersect. Journal of Research on Teaching in Education, 42(3), 255-284.

Frank, K. A., Zhao, Y., \& Borman, K. (2004). Social capital and the diffusion of innovations within organizations: The case of computer technology in schools. Sociology of Education, 77, 148-171.

Glaser, B., \& Strauss, A. (1967). The discovery of grounded theory: Strategies for qualitative research. Chicago, IL: Aldine De Gruyter.

Gottfried, A. E. (1990). Academic intrinsic motivation in young elementary school children. Journal of Educational Psychology, 82, 525-538.

Hew, K. F., \& Brush, T. (2007). Integrating technology in K-12 teaching and learning: Current knowledge gaps and recommendations for future research. Educational Technology Research and Development, 55, 223-252. 
Hancock, D. R., Bray, M., \& Nason, S. A. (2002). Influencing university students' achievement and motivation in a technology course. The Journal of Educational Research, 95(6), 365-372.

ISTE (International Society for Technology in Education). (2008). ISTE NETS for teachers. Retrieved from http://www.iste.org/Content/NavigationMenu/NETS/For Teachers/NETS_for_Teachers.htm

Knezek, D., \& Christensen, R. (2011, April 29). Teachers' attitudes toward information technology. Retrieved from http://www.iittl.unt.edu/IITTL/newiittl/iittl_instruments/ tat/iittl tat main.html

Lee, J., Cerreto, F. A., \& Lee, J. (2010). Theory of planned behavior and teachers decisions regarding use of educational technology. Educational Technology \& Society, 13(1), 152-164.

Lei, J. (2009). Digital natives as preservice teachers: What technology preparation is needed? Journal of Computing in Teacher Education, 25(3), 87-97.

Levin, T., \& Wadmany, R. (2006). Teachers' beliefs and practices in technology-based classrooms: A developmental view. Journal of Research on Technology in Education, 39(2), 157-181.

Ma, W-k., Andersson, R., \& Oslear Streith, K. (2005). Examining user acceptance of computer technology: An empirical study of student teachers. Journal of Computer Assisted Learning, 21, 387-395.

Madden, T. J., Ellen, P. S., \& Ajzen, I. (1992). A comparison of the theory of planned behavior and the theory of reasoned action. Personality and Social Psychology Bulletin, 18(3), 3-9.

Ottenbreit-Leftwich, A., \& Cullen, T. (2006). Preserving the legacy of PT3 tools, strategies, and resources: Knowledge capture artifacts. TechTrends, 50(3), 46-53.

Palak, D., \& Walls, R. T. (2009). Teachers' beliefs and technology practices: A mixed methods approach. Journal of Research on Technology in Education, 47(4), 417-441.

Paraskeva, F., Bouta, H., \& Papagianni, A. (2008). Individual characteristics and computer self-efficacy in secondary education teachers to integrate technology in educational practice. Computers and Education, 50(3), 1084-1091.

Pierson, M. (2001). Technology integration practice as a function of pedagogical expertise. Journal of Research on Computing in Education, 33(4), 413.

Pintrich, P. R., \& De Groot, E. V. (1990). Motivational and self-regulated learning components of classroom academic performance. Journal of Educational Psychology, 82(1), 33-40.

Reeve, J. (2001). Intrinsic motivation and acquisition and maintenance of four experiential states. The Journal of Social Psychology, 129(6), 841-854.

Reeve, J. (2002). Self-determination theory applied to educational settings. In E. L. Deci \& R. M. Ryan (Eds.), Handbook of self-determination research (pp. 183-203). Rochester, NY: University of Rochester Press.

Ryan, R. M., \& Deci, E. L. (2000). Self-determination theory and the facilitation of intrinsic motivation, social development, and well-being. American Psychologist, 55, 68-78.

Sadaf, A., Newby, T., \& Ertmer, P. (2011, April). Investigating preservice teachers ' views and intentions to use web 2.0 tools using decomposed theory of planned behavior. Paper presented at the 2011 American Educational Research Association Annual Meeting, New Orleans, LA. 
Sang, G., Valcke, M., van Braak, J., \& Tondeur, J. (2010). Student teachers' thinking processes and ICT integration: Predictors of prospective teaching behaviors and educational technology. Computers and Education, 54(1), 103-112.

Shiue, Y-M. (2007). Investigating the sources of teachers' instructional technology use through the decomposed theory of planned behavior. Journal of Educational Computing Research, 36(4), 425-452.

Sugar, W., Crawley, F., \& Fine, B. (2005). Critiquing theory of planned behaviour as a method to assess teachers' technology integration attitudes. British Journal of Educational Technology, 36(2), 331-334.

Smarkola, C. (2008). Efficacy of a planned behavior model: Beliefs that contribute to computer usage intentions of student teachers and experienced teachers. Computers in Human Behavior, 24, 1196-1215.

Sølvberg, A. (2003). Computer-related control beliefs and motivation: A panel study. Journal of Research on Technology in Education, 35(4), 473.

Stuart, C., \& Thurlow, D. (2000). Making it their own: Preservice teachers' experiences, beliefs and classroom practices. Journal of Teacher Education, 51(2), 113-121.

Vallerand, R. J., Pelletier, L. G., Blais, M. R., Briere, N. M., Senical, C., \& Vallieres, E. F. (1992). The Academic Motivation Scale: A measure of internal, external and amotivation in education. Educational and Psychological Measurement, 52, 1003-1017.

Ward, L., \& Parr, J. M. (2010). Revisiting and reframing use: Implications for the integration of ICT. Computers and Education, 54(1), 113-122.

Williams, G. C., \& Deci, E. L. (1996). Internalization of biopsychosocial values by medical students: A test of self-determination theory. Journal of Personality and Social Psychology, 70, 767-779.

Wong, H. K. (2004). Induction programs that keep new teachers teaching and improving. NASSP Bulletin, 88(638), 41-58.

Wozney, L., Venkatesh, V., \& Abrami, P. C. (2006). Implementing computer technologies: Teachers' perceptions and practices. Journal of Technology and Teacher Education, 14(1), 173-207.

Direct reprint requests to:

Dr. Theresa A. Cullen

Department of Educational Psychology

Jeannine Rainbolt College of Education

University of Oklahoma

820 Van Vleet Oval

Norman, OK 73019

e-mail: tacullen@ou.edu 